\title{
Perubahan Peranan Wanita Sunda: Studi Kasus di Kota Bandung
}

Siti Komariah

(Universitas Pendidikan Indonesia, Bandung, Indonesia; sosiologiupi@gmail.com)

\begin{abstract}
This writing explores on the sociology of family, especially related to the roles of women in Sundanese societal family, by taking case of the City of Bandung. By qualitative and survey approaches, the writer apprehend the matters by tracking to: women's job; the age of marriage and the right to choose the spouse; the view of women towards the roles of wife, husband, mother; and their views on job and domestic issues. The writer finds out that Sundanese women have got a new condition, like those of bread winning roles, etc.
\end{abstract}

Keywords: family sociology; the role of women; Sundanese women; Bandung women.

\begin{abstract}
Abstrak
Tulisan ini membahas tentang sosiologi keluarga, yaitu yang berkaitan dengan peranan perempuan dalam keluarga masyarakat Sunda, dengan mengambil studi kasus di Kota Bandung. Dengan pendekatan kualitatif dan survey, penulis mendekati masalahnya dengan melihat pada: pekerjaan wanita; umur perkawinan dan hak pemilihan pasangan menikah; pandangan wanita terhadap peranan isteri, suami, ibu; dan pendapat mereka mengenai isu-isu pekerjaan dan isu-isu rumah tangga. Penulis mendapatkan bahwa wanita Sunda sudah mendapatkan kondisi yang baru, yaitu peran sebagai pencari nafkah, selain peran-peran lainnya.
\end{abstract}

Kata kunci: Sosiologi keluarga; peranan perempuan; perempuan Sunda; Wanita Bandung.

\section{A. Pendahuluan}

Peranan wanita Sunda pada masa sekarang telah mengalami perubahan. Wanita Sunda yang semasa dahulu hanya berkecimpung dalam ruang dapur, sumur, kasur, atau sering dikatakan dalam Bahasa Sunda: awewe mah tempatna di dapur (artinya tempat wanita di dapur---di belakang) (Ekadjati, 1995:203); pada waktu ini telah banyak terlibat dalam lapangan publik, baik sebagai pegawai maupun aktif di pelbagai 
organisasi politik, organisasi sosial kemasyarakatan, serta organisasi-organisasi wanita. Hal ini didorong oleh sifat dan karakteristik budaya Sunda yang lentur, adaptif, dan terbuka dan memberikan pengaruh terhadap kelenturan sikap dan tindakan masyarakat Sunda terhadap perkembangan zaman serta melihat segala perubahan itu untuk ngindung ka waktu ngabapa ka zaman (artinya beribu kepada waktu dan berbapak kepada jaman). Kebudayaan Sunda sebagai perangkat acuan, pedoman, dan perangkat kontrol sosial termaklumat dalam ungkapan bahasa Sunda, silih asah, silih asub, silib asib (artinya saling mengasihi, mengasah, dan saling mengasuh dalam menciptakan masyarakat yang tentram serta teratur).

Barangkali memang bukan karena kesundaannya itu sendiri bahwa wanita Sunda itu sudah berubah peranan. Boleh jadi kebutuhan hidup lah yang membuat wanita bekerja, misalnya. Eksistensi hidup lah yang membuat para wanita bekerja (Rahman, 2018: 191). Di lingkungan perkotaan, khasnya Bandung sebagai ibukota Propinsi Jawa Barat, banyak dari golongan wanita yang memasuki lapangan pekerjaan di bidang industri tekstil atau garmen, sehingga menjadi sebagian besar pekerjanya (Rostiyati \& Priyatna, 2017: 263). Alasan mereka melakukan aktivitas di luar rumah sesuai dengan pekerjaannya. Mencari nafkah di kota Bandung karena desa kurang memberikan peluang kerja, untuk memperoleh status (kedudukan dan pengaruh dalam keluarga), autonomy (tidak bergantung secara ekonomi, bebas berbuat atau mandiri), affiliation (mendapat kegembiraan dan banyak teman), dan stimulation (melakukan sesuatu yang baru atau pengalaman).

Memang, wanita sebagai warga negara pada prinsipnya mempunyai hak, kewajiban serta kesempatan yang sama dengan pria di segala kehidupan dan dalam kegiatan pembangunan. Untuk itu kedudukan wanita dalam masyarakat dan perannya 


\section{ARTIKEL}

dalam pembangunan perlu terus ditingkatkan dan diarahkan. Peran wanita dalam pembangunan diharapkan berkembang selaras dengan perkembangan tanggung jawab perannya dalam mewujudkan keluarga sehat, sejahtera, dan bahagia, termasuk perkembangan generasi muda dalam rangka pembangunan manusia seutuhnya (GBHN, 1988).

Mutawali (1987: 13) mengungkapkan peranan wanita dapat dilihat dari dua segi: pertama, peranannya dalam keluarga dan rumah; wanita sebagai pendidik pertama dan utama mempunyai tugas menyiapkan manusia-manusia yang cerdas, sehat, terampil, kreatif, dinamik, produktif dan disiplin. Generasi yang akan datang bergantung harap kepada kemampuan wanita dalam mempersiapkan manusia pembangunan dewasa ini; dan kedua, peranan wanita di luar keluarga dan rumah atau peranannya di masyarakat. Wanita dengan kepribadiannya yang cergas, teliti, cermat, rajin, dan disiplin adalah suatu potensi yang tidak dapat diabaikan dalam memenuhi keperluan tenaga penggerak pembangunan.

Peran wanita sehubungan dengan perkembangan generasi muda, berkaitan dengan fungsi semula jadi wanita dalam hal ini ibu sebagai pembimbing anak, ibu lebih dapat diterima oleh anak muda sebagai penegak norma dan nilai kehidupan dalam keluarga. Hal tersebut berpengaruh pula dalam mengukuhkan norma kehidupan dalam lingkungan masyarakat. Dengan demikian peran penting wanita dalam pembangunan, terutama dalam fungsi keibuannya adalah untuk membina stabiliti sosial (Elliott, 2019). Hal ini selaras dengan pernyataan Ritzer (1988) wanita memegang peranan penting dalam proses sosialisasi anggota keluarga sebagai salah satu upaya investasi sumberdaya keluarga.

\section{B. Metode}




\section{ARTIKEL}

E-ISSN: $2615-5028$

Penelitian ini menggunakan pendekatan kuantitatif dan kualitatif secara bersamaan. Hal ini diasaskan kepada masalah dan tujuan penelitian yang mengarahkan kepada perlunya analisis kuantitatif dan kualitatif untuk saling melengkapi antara satu sama lainnya. Dengan penggabungan dua pendekatan dapat mempertajam hasil analisis kuantitatif, sebagai strategi yang memberikan jalan keluar bagi sosiolog yang sering dihadapkan pada "dualitas struktur", yaitu memahami masyarakat secara makro struktural yang cenderung diterministik dan mikro struktural yang menekankan perlunya penjelasan dan proses kreatif-interaktif (Hoang, 2019). Kemudian Vredenbregt (1997: 89) menyatakan bahwa pendekatan kuantitatif memberi kerangka atas realitas sosial yang telah diteliti dan pendekatan kualitatif akan mampu menempatkan data kuantitatif itu dalam perspektif yang benar. Dengan mengkombinasikan kedua pendekatan ini hasil penelitian akan dapat dicapai dengan lebih memuaskan.

Dalam kaitannya dengan pendekatan kuantitatif, maka metode penelitiannya akan menggunakan metode eksplanatory survey. Metode ini berupaya menjelaskan mengapa suatu peristiwa berlaku dengan menunjukkan sebab dan akibatnya dengan jalan menguji proposisi-proposisi deduksi (hipotesis), karena itu kajian ini sering disebut juga verificative research (Hassan, dkk., 2019). Penelitian survey mengkaji populasi (universe) yang besar ataupun yang kecil, untuk menemukan insidensi, distribusi, dan interrelasi relatif dari variabel-variabel sosiologis dan psikologis atau mempelajari fenomena sosial dengan meneliti hubungan variabel penelitian (Kumar, 2019). Pendekatan kualitatifnya akan lebih menekankan pada instrumen penelitian dan analisa datanya untuk melengkapi temuan-temuan dari penelitian kuantitatif. 


\section{ARTIKEL}

E-ISSN: $2615-5028$

Dengan kedua pendekatan penelitian tadi, berikut adalah kajian tentang perubahan peranan wanita Sunda di Kota Bandung dapat dilihat dari: 1) Pekerjaan wanita, 2) Umur perkawinan dan hak pemilihan pasangan menikah, 3) Pandangan wanita terhadap peranan isteri, suami, ibu, 4) Pendapat mereka mengenai isu-isu pekerjaan dan isu-isu rumah tangga.

Kajian ini merupakan satu tinjauan dan analisis terhadap perubahan peranan wanita Sunda, maka semua populasi penyelidikan ini terdiri dari kaum wanita yang telah berumah tangga. Wanita yang sudah berumah tangga dipilih karena mereka diandaikan memainkan peranan utama dalam pembangunan keluarga. Peranan mereka bukan sahaja penting dalam aktiviti reproduktif, malah juga dalam aktiviti produktif. Walau bagaimanapun, pemilihan wanita yang telah berumah tangga hanya terbatas kepada mereka yang masih bersuami dan dalam lingkungan umur 27 hingga 55 tahun. Batas kepada wanita bersuami dan batas umur berkenaan penting untuk mendapatkan pengkaji melihat hubungan antara wanita, serta hubungan gender antara suami isteri dalam perubahan peranan wanita Sunda khasnya.

Populasi dalam penyelidikan ini, yaitu wanita yang berada di kota Bandung. Bandung sebagai ibu kota Provinsi Jawa Barat dipilih sebagai kawasan kajian, sebab kawasan ini merupakan mitra hadapan ibu kota pemerintah Indonesia serta mempunyai misi sebagai provinsi termaju di Indonesia pada tahun 2010. Mereka adalah pegawai-pegawai sipil pemerintah atau Pegawai Negeri Sipil, TNI (Tentara Nasional Indonesia), (POLRI), Kepolisian Republik Indonesia), Anggota legislatif (Dewan Perwakilan Rakyat). Berasaskan hasil observasi dan penelusuran terhadap dokumen-dokumen resmi diperoleh jumlah populasi seramai 11.298 orang, yang terdiri atas anggota legislatif Provinsi (DPRD Provinsi) Jawa Barat seramai 12 orang 
dan anggota legislative kota Bandung (DPRD Kota) seramai 2 orang. Kedua-duanya berkedudukan di Bandung sehingga menjadi populasi penyelidikan. Pegawai Negeri Sipil seramai 10.553 orang. TNI/POLRI seramai 731 orang. Perincian populasi kajian yang jelas boleh dilihat dalam jadual berikut ini:

Tabel 1

Jumlah Populasi Kajian

\begin{tabular}{|l|c|}
\hline Responden & Jumlah \\
\hline Pegawai Pemerintah & 10.553 \\
Anggota DPR (legislative) & 14 \\
TNI/POLRI & 731 \\
\hline Jumlah & 11.298 \\
\hline
\end{tabular}

Sesuai dengan tujuan kajian ini, prosedur penarikan sampel adalah mengikut cara pengundian sampel dengan teknik sampling menggunakan Purpossive Sampling, karena disesuaikan dengan tujuan penyelidikan, dimana besarnya jumlah sampel ditentukan 300 orang.

Pengumpulan data dilaksanakan melalui dua cara, yaitu, melalui penyelidikan perpustakaan (library research) dan penyelidikan lapangan (field reserach). Penyelidikan perpustakaan digunakan untuk mencari data penyokong (sekunder) bagi masalah kajian yang telah dirumuskan. Caranya ialah dengan membaca bacaan-bacaan yang terpilih dan memeriksa dokumen-dokumen yang ada hubungannya dengan permasalahan yang dikaji berkenaan dengan perubahan peranan wanita Indonesia, amnya, dan wanita Sunda, khasnya. Penyelidikan lapangan digunakan untuk mengumpulkan data asasi (utama) berkenaan dengan persepsi, pendapat, 
kepercayaan, atau sikap terhadap faktor-faktor yang mempengaruhi terhadap peranan wanita Sunda di Indonesia. Penyelidikan lapangan ini menggunakan dua cara, ialah angket (questionare) dan temuduga bebas (in-depth interview).

\section{Hasil dan Pembahasan}

\section{Aspek-aspek Perubahan Peranan}

\section{a. Pekerjaan Wanita}

Responden Wanita Sunda dalam kajian ini terlibat sebagai pegawai di lingkungan pemerintah Indonesia, yang terdiri dari pegawai negeri sipil (pegawai pemerintah) sebanyak 60\%, anggota Legislatif (Dewan Perwakilan Rakyat Daerah) sebanyak 4,67\%, dan Tentara Nasional Indonesia/ABRI sebanyak 15,33 \%, Kekebijakanan Republik Indonesia atau Polis Wanita sebanyak 10\%, dan tidak bekerja atau sebagai ibu rumah tangga sebanyak 10\%. Kenyataan ini membuktikan bahwa wanita mampu berperanan di lingkungan publik yang asalnya merupakan dunia lelaki. Hal yang menggembirakan, bahwa bilangan wanita yang terbanyak berperanan sebagai pegawai negeri sipil atau pegawai pemerintah. Hal ini dikarenakan kesempatan terbuka bagi semua warga negara baik lelaki maupun wanita untuk ikut dalam penseleksian penerimaan pegawai pemerintah.

Wanita Sunda telah memasuki lapangan publik selain ianya berkiprah di lapangan domestik. Peranan wanita Sunda di lapangan pekerjaan dipengaruhi oleh motivasi ekonomis-materil, misalnya memperoleh penghasilan bagi keluarga, serta motivasi mental-spiritual diantaranya mempraktikkan ilmu pengetahuan dan keterampilan yang diperoleh; meningkatkan karier; serta mencari kepuasan mental. 
Dengan cara itu, wanita dapat memantapkan kepribadiannya sendiri, sehingga dapat menambah kedalaman hidupnya, memiliki arti hidupnya sebagai seorang isteri; dan membuat dirinya terasa ada. Karena dengan kesedaran akan eksistensi dirinya ini, iaya akan merasakan hidupnya itu lebih bermakna, tidak mati.

Semasa lalu, diferensiasi peranan terjadi pada masyarakat Sunda; ayah adalah kepala keluarga yang bertugas tidak hanya memimpin keluarganya, tetapi juga mencari nafkah untuk menghidupi tanggungannya itu. Semasa kini, seorang ibu selain memelihara dan mengasuh anak-anak yang dilahirkan dari perkawinan atau perkawinan sebelumnya; seorang ibu juga mempunyai peranan ekonomi yang tidak kurang fungsinya dari ayah. Ianya mencari nafkah, bahkan jika keadaan memaksa, menggantikan suami untuk menghidupi keluarga atau kanak-kanak yang menjadi tanggungannya (hasil wawancara).

Selain itu, dahulu dalam keluarga Sunda terjadi differensiasi yang tegas antara suami dan isteri; isteri sebagai ibu rumah tangga yang berkedudukan sebagai ibu, maka isteri harus tinggal di rumah, seperti tercermin dalam ungkapan kasur, dapur, sumur, (peran perempuan sekitar tempat tidur, dapur, dan sumur), sedangkan suami mencari nafkah. Tetapi semasa sekarang, tidak seperti dahulu, dan mulai berubah. Hal ini akibat adanya kesedaran bahwa kehidupan keluarga merupakan tanggung jawab bersama antara isteri dan suami, seperti diungkapkan dalam temu bual bahwa ngayuh rumah tangga mah kudu saheuyeuk sapihanean (dalam mengurus rumah tangga harus ada kerja sama saling membantu; rumah tangga mah kudu ka cai jadi saleuni ka darat jadi salogak (rumah tangga itu harus kerjasama dan rukun antara suami dan isteri). 


\section{ARTIKEL}

E-ISSN: $2615-5028$

Berperanannya wanita Sunda dalam pekerjaan, membuktikan bahwa wanita Sunda dapat bersaing dengan lelaki seiring dengan kualitas pendidikan yang dicapainya, sehingga wanita dapat berperanan sebagai subyek pembangunan di samping sebagai objek pembangunan bangsa dan negara. Tingkat pendidikan responden dalam penelitian ini menunjukkan hal yang menggembirakan, dimana tingkat Doktor/PH.D (Ijazah tiggi) sebanyak 8,34\%, Master (Pasca Siswajah) sebanyak 25,33\%, Sarjana sebanyak 48\% 70,3\%, dan Sekolah Menengah Atas sebanyak 18,33\%.. Hal ini berbeda dengan keadaan sebelumnya, dimana dalam masyarakat Sunda ada ungkapan "awewe mah tong sakola lubur-lubur tening, engke ge balik ka dapur deui", (artinya wanita jangan bersekolah sampai ke tingkat yang lebih tinggi, sebab pada akhirnya akan kembali lagi ke dapur). Jadi, pandangan orang tua (adat istiadat dan kearifan lokal) terhadap pendidikan wanita, sudah mengalami perubahan. Justru masa kini, pendidikan wanita harus tinggi karena mengemban tugas sebagai subjek pembangunan, terutama dalam berpartisipasi membangun manusia Indonesia seutuhnya serta berperanan dalam kegiatan pembangunan. Kualitas pendidikan bagi orang Sunda merupakan harapan orang tua terhadap anak, dan merupakan pola kepribadian yang tersirat dalam ungkapan simbolik; cageur, bageur, bener, pinter, yaitu agar anak sentiasa sehat, jujur, benar, dan pandai dalam membawa diri di dalam kehidupan masyarakat (Ekadjati, 1984:219).

Perkembangan zaman membawa konsekuensi betapa pentingnya pendidikan bagi masyarakat Sunda. Karena itu, orang Sunda menekankan pentingnya pendidikan bagi anak, seperti terungkap dalam ucapan orang tua kepada anak-anaknya, nuntut elmu teh wajib hukumna (menuntut ilmu itu wajib hukumnya); tuntut elmu sanajan ka nagri Cina (tuntutlah ilmu sekalipun ke negeri Cina; dan diajar sing junun da elmu mah moal 


\section{ARTIKEL}

ridu mamawa (belajarlah dengan rajin karena memiliki pengetahuan tidak akan repot membawanya). Masyarakat Sunda pun mengakui pentingnya ilmu untuk kehidupan di dunia dan di akhirat, seperti dalam ungkapan "ilmu tuntut dunya siar" (carilah ilmu, dan perolehlah dunia).

Menuntut ilmu bagi orang Sunda, boleh diperoleh dari ti papada urang, tina daluang, tina luang (Adimihardja, 2008). Ti papada urang (dari sesama manusia), memiliki makna bahwa seseorang boleh belajar dari kawan, teman, atau saudara yang kebetulan memiliki pengetahuan yang luas. Tina daluang (dari kertas); berarti seseorang boleh belajar memperoleh ilmu pengetahuan, karena diberikan oleh orang dengan menunjukkan tulisan-tulisan. Seseorang akan memiliki ilmu pengetahuan apabila banyak membaca. Belajar di sekolah, termasuk wujud dari belajar tina daluang. Daluang berarti kertas atau buku. Sementara Tina luang (dari waktu), mengandungi makna memperoleh pengetahuan dari pengalaman. Luang berarti pengalaman. Tingkat pendidikan yang dicapai wanita Sunda telah menggambarkan implementasi wanita Sunda dalam mendapatkan ilmu pengetahuan, yang diperoleh melalui daluang (lembaga pendidikan persekolahan).

\section{b. Umur Perkawinan dan Hak Pemilihan Pasangan Menikah}

\section{1) Umur Perkawinan Pertama}

Umur Pelaksanaan perkawinan wanita Sunda, masa sekarang ini sudah mengalami perubahan. Berdasarkan jawapan responden, umur pertama menikah paling banyak (64\%) antara 23-27 tahun; sebanyak 16\% antara umur 28-32 tahun; sebanyak 10\% antara umur 33-37 tahun, dan sisasnya sebanyak 10\% antara 18-22 


\section{ARTIKEL}

E-ISSN: $2615-5028$

tahun. Hal ini diakibatkan semakin matangnya pemikiran wanita ataupun orang tua wanita dalam mempersiapkan usia yang paling baik bagi anak-anaknya dalam membentuk keluarga yang sakinah, mawaddah, warahmah (saling mencintai, mengasihi dan menyayangi).

Di samping itu, sebelum berlangsungnya perkawinan dalam masyarakat Sunda terdapat pertimbangan berkenaan dengan bobot, bebet, bibit (kekayaan, ketampanan/kecantikan, dan keturunan) untuk pasangan hidup anak-anaknya. Jika seorang wanita atau lelaki sudah dewasa dan dapat mencari nafkahnya sendiri, maka ada ungkapan geus meujeubna bumen-bumen jeung kurenan (sudah waktunya untuk membentuk keluarga sendiri dengan melalui perkawinan yang akan menghasilkan anak-anak) (Ekadjati, 1984:43).

Kematangan umur perkawinan bagi wanita Sunda ternyata bertolak belakang dengan adat dan kebiasaan dalam masyarakat Sunda sebelumnya. Perkawinan dalam masyarakat Sunda, terutama di perdesaan masih sahaja dilakukan di bawah umur, sehingga sering dinamakan Perkawinan Di Bawah Umur. Umur calon pengantin, biasanya berada di bawah ketentuan Undang-Undang Perkawinan Nombor 1 Tahun 1974; yaitu lelaki kurang dari 19 tahun, dan wanita kurang dari 16 tahun.

Sebutan parawan jomlo atau peratu (Perawan tua) bagi seorang gadis yang sudah besar tetapi belum kawin menyebabkan perasaan malu, baik bagi si gadis yang bersangkutan maupun bagi orang tuanya, bahkan kerabat si gadis itu. Peribahasa kawin ayeuna isuk pepegatan (kawin hari ini, besok bercerai) mencerminkan kehendak demikian dalam pandangan masyarakat Sunda. Hal itu lebih baik dari anak wanita tidak kawin sama sekali atau kawin dalam usia lanjut, walaupun bagi masyarakat Sunda perkawinan itu sendiri dianggap sakral. 


\section{ARTIKEL}

E-ISSN: $2615-5028$

\section{2) Hak Pemilihan Pasangan Menikah}

Dalam pemilihan pasangan menikah, sebanyak 96\% wanita Sunda melakukan pilihannya sendiri, dan sisanya sebanyak $4 \%$ berdasarkan pilihan orang tua. Pemilihan pasangan menikah bagi wanita Sunda semasa ini lebih demokratis sebab anak bisa menentukan pilihan calon suaminya berdasarkan keinginannya. Jika dibandingkan dengan masa lalu, biasanya penentuan calon suami bagi wanita Sunda lebih banyak dipertimbangkan oleh orang tua dan nenek (ibu dari ayah) seringkali dimintai pendapat dan nasehatnya dalam menentukan jodoh dan menerima pelamaran (Ekadjati, 1984: 37).

\section{Pandangan Wanita Terhadap Peranan Isteri, Suami, Ibu}

Pembentukan keluarga dalam masyarakat Sunda sebetulnya merupakan ikatan yang suci antara suami dan isteri, karena itu urusan rumah tangga semestinya menjadi tanggung jawab bersama, bukan hanya menjadi tanggung jawab isteri sahaja, tetapi juga suami. Karena itu perlu adanya keseimbangan, keserasian dan keselarasan atau sharing dalam dalam menjalankan peranan baik suami maupun isteri. Suami dan isteri merupakan mitra yang harus saling mengisi dan bekerja sama membangun kekuatan sinergi dalam kehidupan keluarga khasnya. Kemitraan atau kebersamaan lelaki dan wanita bisa saling menguntungkan---win-win strategy--- sama-sama menang, bukan menang-menangan.

Walaupun di satu sisi wanita Sunda suadah mengalami perubahan peranan dalam berbagai aspek kehidupan, namun jika memperhatikan kondisi objektif wanita dibanding dengan lelaki secara keseluruhan masih tertinggal secara kuantiti dan 


\section{ARTIKEL}

E-ISSN: $2615-5028$

kualitas dalam kehidupan politik, ekonomi, pendidikan karena nilai-nilai budaya patriarki dan perlakuan diskriminatif, maka perlu kegiatan-kegiatan penyadaran (awareness rising) terutama mengubah cara pandang dan pola pikir (mind set) kita---lelaki dan wanita----tentang prinsip-prinsip demokrasi yang menjamin kesetaraan, hak asasi manusia, supremasi hukum, dan keadilan. Ketimpangan gender dalam lembaga politik, lapangan pekerjaan, pendidikan, hukum dan perundang-undangan tidak mungkin terkejar tanpa ada suatu tindakan khusus atau affirmative action, yang dimaksudkan untuk mempercepat kesetaraan yang berkeadilan. Pandangan wanita mengenai peranan isteri, peranan suami, peranan ibu dapat dilihat dalam tabel berikut.

Tabel 2

Pandangan wanita Mengenai Peranan Isteri, Peranan Suami, Peranan Ibu

\begin{tabular}{|c|c|c|c|c|c|c|}
\hline No. & Pernyataan & SS & S & TAP & TS & STS \\
\hline 1 & Peranan Isteri & 165 & 135 & & & \\
\hline 2. & Isteri berperanan untuk & 146 & 154 & & & \\
\hline & berkiprah di lapangan publik & & & & & \\
\hline 3. & $\begin{array}{l}\text { Isteri berperanan dalam } \\
\text { menafkahi keluarga }\end{array}$ & 55 & 88 & 145 & & 12 \\
\hline 4. & $\begin{array}{l}\text { Isteri berhak menentukan } \\
\text { pilihan pekerjaannya }\end{array}$ & 125 & 165 & 10 & & \\
\hline 5. & $\begin{array}{l}\text { Isteri berhak menentukan } \\
\text { tempat bekerja }\end{array}$ & 99 & 176 & 25 & & \\
\hline 6. & $\begin{array}{l}\text { Isteri berhak menentukan } \\
\text { pilihan kemasukan organisasi }\end{array}$ & 165 & 135 & & & \\
\hline 7. & $\begin{array}{l}\text { Isteri merupakan pendamping } \\
\text { suami }\end{array}$ & 135 & 145 & 20 & & \\
\hline 8. & $\begin{array}{l}\text { Isteri berperanan mengurus } \\
\text { suami }\end{array}$ & 149 & 151 & & & \\
\hline 9. & $\begin{array}{l}\text { Isteri harus tunduk dan patuh } \\
\text { pada suaminya }\end{array}$ & 137 & 163 & & & \\
\hline 10. & $\begin{array}{l}\text { Kedudukan isteri tergantung } \\
\text { kepada suaminya }\end{array}$ & & & 25 & 125 & 150 \\
\hline 11. & $\begin{array}{l}\text { Tugas isteri adalah di dapur, } \\
\text { sumur, kasur }\end{array}$ & & & & 123 & 177 \\
\hline
\end{tabular}


ARTIKEL

E-ISSN: $2615-5028$

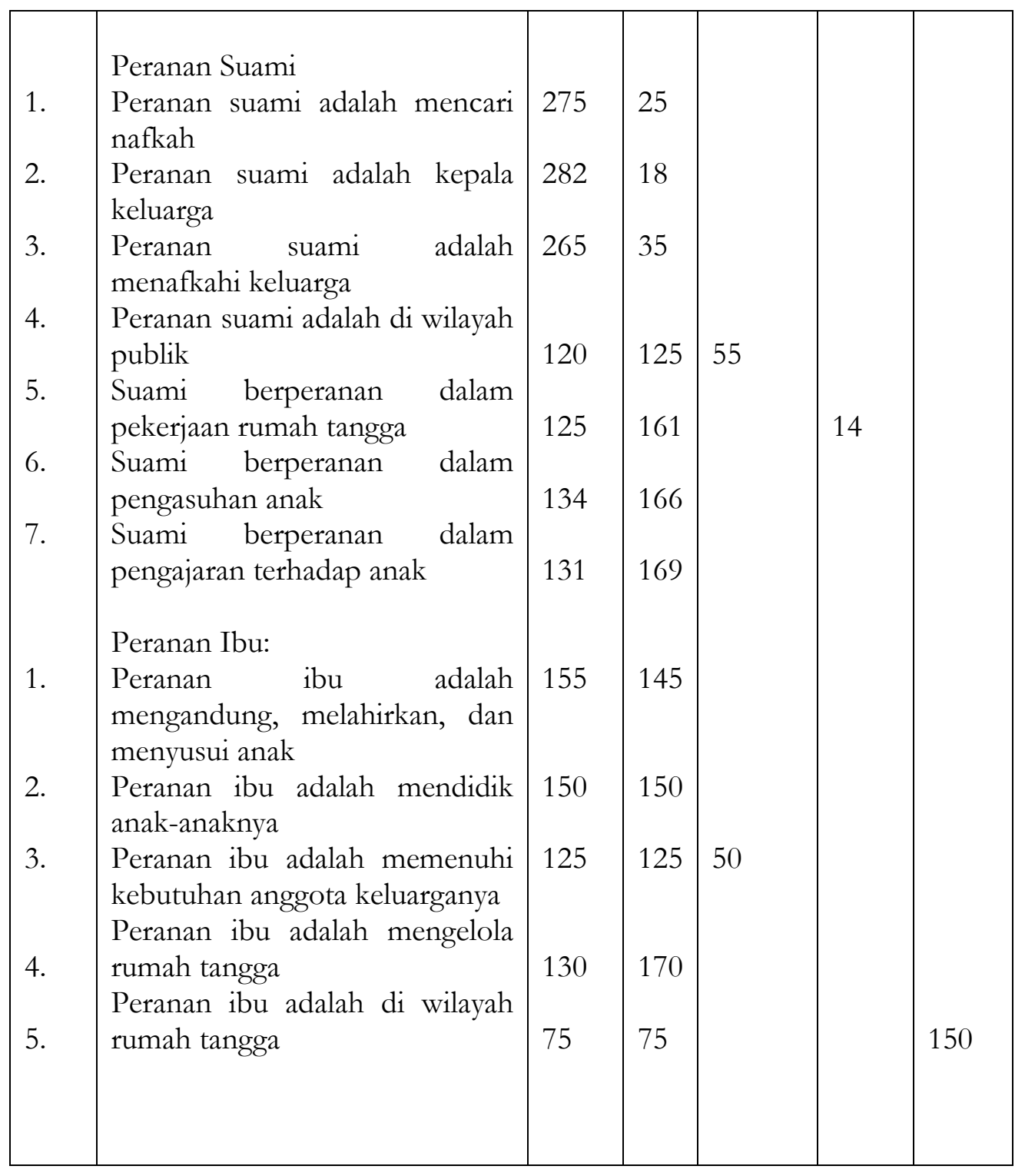

\section{a. Peranan Istri}

Isteri adalah partner suaminya sebanyak 55,00\% menyatakan sangat setuju, dan sebanyak 45,00\% menyatakan setuju; Isteri berperanan untuk berkiprah di lapangan publik, sebanyak 48,67\% menyatakan sangat setuju, dan sebanyak 51,33\% menyatakan setuju; Isteri berperanan dalam menafkahi keluarga, sebanyak 18,33\% 


\section{ARTIKEL}

E-ISSN: $2615-5028$

menyatakan sangat setuju, sebanyak 29,33\% menyatakan setuju, sebanyak 48,33\% menyatakan tidak ada pilihan, sebanyak 4,00\% menyatakan sangat tidak setuju.

Isteri berhak menentukan pilihan pekerjaannya, sebanyak 41,67\% menyatakan sangat setuju, sebanyak 55,00\% menyatakan setuju, sebanyak 55,00\% menyatakan setuju, sebanyak 3,33\% menyatakan tidak ada pilihan; Isteri berhak menentukan tempat bekerja, sebanyak 33,00\% menyatakan sangat setuju, sebanyak 58,67 menyatakan setuju, dan sebanyak 8,33 menyatakan tidak ada pilihan; Isteri berhak menentukan pilihan kemasukan organisasi, sebanyak 55,00\% menyatakan sangat seuju, dan sebanyak 45,00\% mentarakan setuju; Isteri merupakan pendamping suami, sebanyak 45,00\% mentarakan sangat setuju, sebanyak 48,33\% menyatakan setuju, dan 6,67\% menyatakan tidakada pilihan; Isteri berperanan mengurus suami, sebanyak 49,97\% menyatakan sangat setuju, dan sebanyak 50,33\% menyatakan setuju; Isteri harus tunduk dan patuh pada suaminya, sebanyak 45,67\% menyatakan sangat setuju, dan sebanyak 54,33\% menyatakan setuju; kedudukan isteri tergantung kepada suaminya50,00\% menyatakan sangat tidak setuju, sebanyak 41,67\% menyatakan tidak setuju, dan sebanyak 8,33\% menyatakan tidak ada pilihan; Tugas isteri adalah di dapur, sumur, kasur, sebanyak 41,00\% menyatakan tidak setuju, dan sebanyak $59,00 \%$ menyatakan sangat tidak setuju.

Perubahan peranan isteri pada masyarakat Sunda ternyata unik, Peranan isteri tidak hanya berurusan dengan lingkungan domestik (dapur, sumur, dan kasur), tetapi sudah merambah ke lapangan publik, dengan ditandai adanya hak istri dalam menentukan pilihan pekerjaannya, menentukan tempat kerjanya, menentukan pilihan kemasukan organisasi kemasyarakata, akan tetapi nilai-nilai lokal yang saling menghargai dan melengkapi antara suami istri tetap dijaga untuk menciptakan 


\section{ARTIKEL}

E-ISSN: $2615-5028$

keseimbangan dan kerukunan di dalam rumah tangga, seperti isteri harus patuh kepada suaminya sebagai pemimpin di dalam rumah tangga selama dia memegang amanah kepemimpinannya di jalan yang benar; akan tetapi istri juga partner suaminya di dalam membina rumah tangganya; sehingga kedudukan isteri tidak selalu tergantung kepada suaminya. Hal ini merupakan perubahan yang mencolok jika dibandingkan dengan masa lalu, sebab ada ungkapan istri mab dulang tinande, najan dibawa ka liang cocopet ge daek (artinya isteri itu harus mengikuti suaminya, walaupun dibawa ke dalam kesusahan juga mau).

\section{b. Peranan Suami}

Peranan suami adalah mencari nafkah, sebanyak 91,67\% menyatakan Sangat Setuju, sebanyak 8,33\% menyatakan Setuju. Peranan suami adalah kepala keluarga sebanyak 94,00\% menyatakan Sangat Setuju, sebanyak 6,00\% menyatakan Setuju. Peranan suami adalah menafkahi keluarga sebanyak 88,33\% menyatakan Sangat Setuju, sebanyak 11,67\% menyatakan Setuju. Peranan suami adalah di wilayah publik, sebanyak 40,00\% menyatakan Sangat Setuju, sebanyak 41,67\% menyatakan Setuju, dan sebanyak 18,33\% menyatakan tidak ada pilihan. Suami berperanan dalam pekerjaan rumah tangga sebanyak 41,67\% menyatakan Sangat Setuju, sebanyak 53,66\% menyatakan Setuju, dan sebanyak 4,67 \% menyatakan Tidak Setuju. Suami berperanan dalam pengasuhan anak, sebanyak 44,67 \% menyatakan Sangat Setuju, sebanyak, 55,33\% menyatakan Setuju. Suami berperanan dalam pengajaran terhadap anak, sebanyak 43,67 \% menyatakan Sangat Setuju, sebanyak 56,33\% smenyatakan Setuju. 


\section{ARTIKEL}

E-ISSN: $2615-5028$

Peranan suami di lingkungan masyarakat Sunda di Kota Bandung pun mengalami perubahan ditandai dengan jawaban dari responden, bahwa suami berperanan pula dalam pekerjaan rumah tangga, pengasuhan anak, dan pengajaran terhadap anak-anaknya. Perubahan peranan ini sebagai bentuk kerjasama (sharing) yang dilakukan oleh suami kepada isterinya, tetapi tanpa meninggalkan tugas utamanya sebagai suami yaitu menafkahi keluarganya dan menjadi pepimpin bagi keluarganya.

\section{c. Peranan Ibu}

Peranan ibu adalah mengandung, melahirkan, dan menyusui anak, sebanyak 51,67\% menyatakan Sangat Setuju, dan sebanyak 48,33\% menyatakan Setuju. Peranan ibu adalah mendidik anak-anaknya, sebanyak 50,00\% menyatakan Sangat Setuju, dan sebanyak 50,00\% menyatakan Setuju. Peranan ibu adalah memenuhi kebutuhan anggota keluarganya, sebanyak 41,67\% menyatakan Sangat Setuju, sebanyak 41,67\% menyatakan Setuju, dan 16,66\% menyatakan tidak ada pilihan. Peranan ibu adalah mengelola rumah tangga sebanyak 43,33\% menyatakan Sangat Setuju, dan sebanyak 56,67\% menyatakan Setuju. Peranan ibu adalah di wilayah rumah tangga, sebanyak 25,00 \%menyatakan Sangat Setuju, sebanyak 25,00\% menyatakan Setuju, dan sebanyak 50,00\% menyatakan Sangat Tidak Setuju.

Peranan ibu dalam masyarakat Sunda di Kota Bandung ternyata mengalami perubahan pula. Dari jawaban responden dapat dikemukakan bahwa peranan ibu ti tidak hanya dilakukan di wilayah rumah tangga, tetapi bisa dilakukan dalam lingkungan pekerjaannya. Dengan kemampuan dan kekuatan yang dimiliki oleh 


\section{ARTIKEL}

E-ISSN: $2615-5028$

seorang ibu akan menjadi dorongan kuat untuk mengaktualisasikan keprofesionalannya dalam lingkungan pekerjaannya.

\section{Pendapat Responden Mengenai Isu-isu Pekerjaan}

\section{a. Kenaikan pangkat}

Isu-isu yang berkenaan dengan wanita di lingkungan pekerjaan khasnya kenaikan pangkat dalam kajian ini; diantaranya melihat permasalahan diskriminasi gender dalam lapangan pekerjaan, sehingga apakah wanita masih dirugikan? Wanita pada umumnya dianggap kurang memiliki kemampuan kepemimpinan dan profesi disebabkan oleh pandangan stereotipe terhadap wanita.

Dalam kajian ini dikemukakan beberapa pendapat responden mengenai isuisu pekerjaan yang berhubung kait dengan kenaikan pangkat, baik dilihat dari kemampuan kepemimpinan dan kemampuan profesional wanita di lingkungan kerjanya. Pendapat Responden mengenai Isu-isu Pekerjaan khussnya mengenai kenaikan pangkat ditinjau dari kemampuan kepemimpinan dan profesional wanita dapat dilihat dari tabel berikut.

Tabel 3

Pendapat Responden mengenai Kemampuan Kepemimpinan dan Profesional Wanita

\begin{tabular}{|c|c|c|c|c|c|c|}
\hline $\mathrm{No}$ & Pernyataan & SS & $\mathrm{S}$ & TAP & TS & STS \\
\hline 1. & $\begin{array}{l}\text { Wanita kurang cakap memahami } \\
\text { arahan pemimpin }\end{array}$ & & & & 146 & 154 \\
\hline 2. & $\begin{array}{l}\text { Wanita kurang cakap mengikuti cara } \\
\text { berfikir pemimpin }\end{array}$ & & & & 145 & 155 \\
\hline 3. & $\begin{array}{l}\text { Wanita kurang cakap bekerja sesuai } \\
\text { dengan selera pemimpin }\end{array}$ & & & & 139 & 161 \\
\hline $\begin{array}{l}4 . \\
5 .\end{array}$ & $\begin{array}{l}\text { Wanita kurang cakap melaksanakan } \\
\text { kebijakan pemimpin } \\
\text { Wanita kurang dipercaya memegang }\end{array}$ & & & & 144 & 156 \\
\hline
\end{tabular}

Temali: Jurnal Pembangunan Sosial, Volume 2 Nomor 2 Tahun 2019; (354-384) 


\section{ARTIKEL}

E-ISSN: $2615-5028$

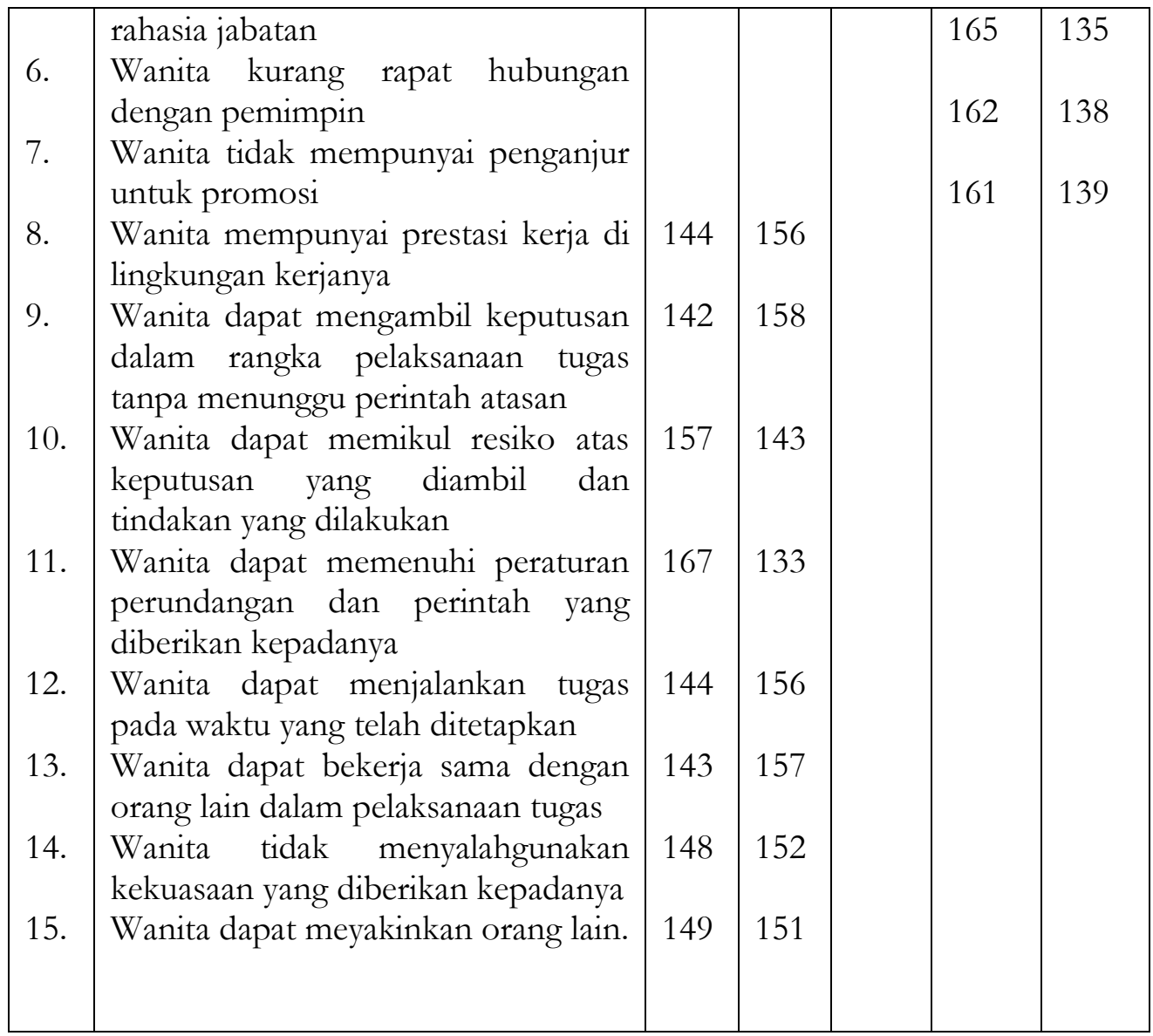

Jawaban responden terhadap kemampuan kepemimpinan dan kemampuan profesional yang dimiliki oleh wanita Sunda di Kota Bandung ternyata sangat menggembirakan, karena sebanyak 48,67\% responden menyatakan tidak setuju , dan sebanyak 51,33\% menyatakan sangat tidak setuju bahwa wanita kurang cakap memahami arahan pemimpin. Sebanyak 48,33\% responden menyatakan tidak setuju, dan sebanyak 51,67\% menyatakan sangat tidak setuju bahwa wanita kurang cakap mengikuti cara berfikir pemimpin. Sebanyak 46,33\% responden menyatakan tidak setuju, dan sebanyak 53,67\% menyatakan sangat tidak setuju bahwa wanita kurang cakap bekerja sesuai dengan selera pemimpin. Sebanyak 48,00\% responden menyatakan tidak setuju, dan sebanyak $52,00 \%$ responden menyatakan sangat tidak setuju bahwa wanita kurang cakap melaksanakan kebijakan pemimpin. Sebanyak 55\% 


\section{ARTIKEL}

E-ISSN: $2615-5028$

responden menyatakan tidak setuju, dan sebanyak 45\% menyatakan sangat tidak setuju bahwa wanita kurang dipercaya memegang rahasia jabatan. Sebanyak 54\% responden menyatakan tidak setuju, dan sebanyak 46\% menyatan sangat tidak setuju bahwa wanita kurang rapat hubungan dengan pemimpin. Sebanyak 53,67\% responden menyatakan tidak setuju, damn sebanyak 46,33\% menyatakan sangat tidak setuju bahwa wanita tidak mempunyai penganjur untuk promosi.

Sebanyak 48\% responden menyatakan sangat setuju, dan sebanyak 52\% menyatakan setuju bahwa wanita mempunyai prestasi kerja di lingkungan kerjanya. Sebanyak $47,33 \%$ responden menyatakan sangat setuju, dan sebanyak 52,67\% responden menyatakan setuju bahwa wanita dapat mengambil keputusan dalam rangka pelaksanaan tugas tanpa menunggu perintah atasan. Sebanyak 52,33\% responden menyatakan sangat setuju, dan sebanyak $47,67 \%$ menyatakan setuju bahwa wanita dapat memikil resiko atas keputusan yang diambil dan tindakan yang dilakukan. Sebanyak 55,67\% responden menyatakan sangat setuju, dan seranai $44,33 \%$ menyatakat setuju bahwa wanita dapat memenuhi peraturan perundangan dan perintah yang diberikan kepadanya. Sebanyak 48,00\% responden menyatakan sangat setuju, dan sebanyak 52,00\% menyatakan setuju bahwa wanita dapat menjalankan tugas pada waktu yang telah ditetapkan. Sebanyak 49,33\% responden menyatakan sangat setuju, dan sebanyak 50,67\% responden menyatakan setuju bahwa wanita dapat bekerja sama dengan orang lain dalam pelaksanaan tugas. Sebanyak 49,67\% responden menyatakan sangat setuju, dan sebanyak 50,33\% menyatakan setuju bahwa wanita tidak menyalahgunakan kekuasaan yang diberikan kepadanya. 


\section{ARTIKEL}

E-ISSN: $2615-5028$

Dalam kajian ini ternyata pandangan responden mengenai isu-isu pekerjaan, khususnya menyangkut kenaikan pangkat bagi pekerja wanita ternyata pandangannya positif bahwa wanita mempunyai kemampuan kepemimpinan dan kemampuan profesional sehingga sudah sewajarnya tidak terjadi diskriminasi terhadap pekerja lelaki dan pekerja wanita.

Stereotaip yang dilekatkan kepada wanita sebagai karakter feminin: yang lemah lembut, emosional, penurut, mengalah, dan sebagainya harus dijadikan sumber kekuatan sehingga wanita dapat mengembangkan mengenai konsep kekuasaan wanita (women power). Women power mengintegrasikan kualitas wanita dengan beberapa karakteristik lelaki, sehingga kedua atribut itu memiliki nilai yang sama. Dengan ungkapan lain kualitas lelaki dan wanita tidaklah bertentangan. Karena itu dalam kelembutan dan kasih sayang justru terpendam kekuatan yang dahsyat. Kekuasaan wanita yang dapat mengasah sisi keibuannya yang selalu tanggap terhadap kebutuhan orang lain untuk menyelesaikan setiap agenda pekerjaannya, selain itu kekuasaan wanita mencakup gagasan memberdayakan orang lain, bukan menginjak orang lain. Sehingga kekuasaan dimaknai sebagai kemampuan melaksanakan sesuatu yang berguna bagi orang lain. Untuk itu jawatan yang diduduki wanita merupakan sarana untuk memberdayakan, bukan memperdayakan orang lain.

\section{b. Tantangan Kerja Domestik}

Cabaran kerja domestik yang dialami wanita di Kota Bandung ternyata wanita mengalami masalah dual job atau dual role. Hal ini seperti terlihat dalam tabel berikut ini. 


\section{ARTIKEL}

E-ISSN: $2615-5028$

Tabel 4

Cabaran Kerja Domestik

\begin{tabular}{|l|l|l|l|l|l|l|}
\hline No & Pernyataan & SS & S & TAP & TS & STS \\
\hline 1. & Wanita mengalami dwiperanan & 241 & 59 & & & \\
2. & $\begin{array}{l}\text { Beban kerja domestik wanita lebih } \\
\text { berat dibandingkan lelaki }\end{array}$ & 155 & 145 & & & \\
3. & $\begin{array}{l}\text { Wanita yang bekerja dikehendaki } \\
\text { menunaikan tugas asasi sebagai ibu } \\
\text { rumah tangga }\end{array}$ & 175 & 125 & & & \\
\hline
\end{tabular}

Tabel di atas menggambarkan jawapan responden tentang pendapat responden mengenai isu-isu pekerjaan khasnya berkenaan dengan cabaran kerja domestik, adakah wanita mengalami masalah dual job. Sebanyak 241 orang (80,33\%) menyatakan sangat setuju bila wanita megalami dwitugas; sedangkan sisanya sebanyak 59 orang $(19,67 \%)$ menyatakan setuju. Sebanyak 155 orang (51,67\%) menyatakan sangat setuju bahwa beban kerja domestik wanita lebih berat dibandingkan dengan lelaki, dan sisanya sebanyak 145 orang (48,33\%) menyatakan setuju. Sebanyak 175 orang $(58,33 \%)$ responden menyatakan sangat setuju bila wanita yang bekerja dikehendaki menunaikan tugas dasarnya sebagai ibu rumah tangga, dan 125 orang $(41,67 \%)$ menyatakan setuju.

Penglibatan wanita dalam lapangan publik khususnya dunia kerja dapat dikatakan sebagai satu gejala positif. Namun, mereka mengalami gejala dwiperanan (dual-role) yang harus dipikul wanita. Kini keadaan telah berubah. Wanita telah keluar dari rumah untuk menjalankan tugas-tugas di pejabat, namun tugasnya di rumah tetap dikehendaki menunaikan tugas dasarnya sebagai ibu rumah tangga. Dengan kata lain wanita di kota Bandung mempunyai dwi peranan sebagai pekerja dan sebagai ibu rumah tangga. 


\section{ARTIKEL}

E-ISSN: $2615-5028$

Di lingkungan keluarga peningkatan peranan wanita menimbulkan beban ganda. Pada satu sisi wanita berperanan dalam lapangan pekerjaan, di sisi lain nilai budaya masyarakat Sunda masih membagi pekerjaan domestik adalah tanggung jawab isteri. Hal ini perlu adanya pemecahan masalah sehingga tidak menimbulkan konflik dalam keluarga, akan tetapi justru harus mendatangkan ketenangan, keharmonisan, keserasian, dan keselarasan dalam kehidupan keluarga atau dalam ungkapan Sunda repeh, rapih, tiis ceuli herang mata (artinya kehidupan keluarga yang harmonis, beres, tidak terjadi percekcokan, dan pertengkaran). Jika wanita menghadapi cabaran perubahan dalam peranannya, hal ini bisa dilakukan oleh pasangan suami isteri khasnya masyarakat Sunda dengan duduk bersama bermusyawarah membicarakan berbagai persoalan yang terjadi dalam mkeluarga, sehingga isteri dan suami bida saling mengerti, mamahami, menghargai, dan melakukan perbaikan-perbaikan dalam mengarungi kehidupan keluarga, karena tujuan dari pembentukan keluarga itu sakral.

\section{Pendapat Responden Mengenai Isu-Isu Rumah Tangga}

\section{a. Ekspektasi Suami}

Pengharapan dari suami terhadap wanita khususnya kepada wanita yang terlibat dalam lingkungan publik seperti terlihat dalam tabel berikut.

Tabel 5

Pendapat Responden tentang Pengharapan Suami terhadap Isteri

\begin{tabular}{|l|l|l|}
\hline Pengharapan dari Suami & Jumlah & Peratus \\
\hline Untuk memenuhi kebutuhan ekonomi & 100 & 33,33 \\
Untuk memperoleh status Sosial & 100 & 33,33 \\
Untuk Kepuasan batin & 100 & 33,34 \\
\hline Jumlah & & \\
\hline
\end{tabular}


Berdasarkan pendapat responden, pengharapan dari suami terhadap isteri, sebanyak 33,33\% menyatakan untuk memenuhi kebutuhan ekonomi keluarga, 33,34\% untuk memperoleh status sosial, dan sebanyak 33,34\% untuk kepuasan batin. Pada dasarnya pengharapan dari suami berimbang antara pemenuhan kebutuhan ekonomi, perolehan status sosial, dan kepuasan batin.

\section{b. Jumlah jam kerja di rumah}

Jam buat kerja di rumah bagi wanita lebih panjang dibandingkan dengan jam buat kerja lelaki. Rincian jam buat kerja rumah dapat dilihat dalam tabel berikut.

Tabel 6

Jumlah Jam Buat Kerja Rumah

\begin{tabular}{|l|rl|rr|}
\hline Jam Buat Kerja Rumah & \multicolumn{2}{|c|}{ Isteri } & \multicolumn{2}{c|}{ Suami } \\
& Jumlah & Peratus & Jumlah & Peratus \\
\hline 2 jam & & & 155 & 51,67 \\
3 jam & & & 100 & 33,33 \\
4 jam & & & 25 & 8,34 \\
6 jam & 75 & 25,00 & 10 & 3,33 \\
8 jam & 125 & 41,67 & 10 & 3,33 \\
9 jam & 45 & 15,00 & & \\
10 jam & 25 & 8,33 & & \\
11 jam & 30 & 10,00 & & \\
& & & & \\
\hline Jumlah & 300 & 100,00 & 300 & \\
\end{tabular}

Berdasarkan tabel di atas, jumlah jam buat kerja rumah ternyata banyak dilakukan oleh isteri. Sebanyak 25, 00\% menyatakan 6 jam, sebanyak 41,67\% menyatakan 8 jam, sebanyak 15,00\% menyatakan 9 jam, sebanyak 8,33\% menyatakan 10 jam, dan sebanyak 10\% menyatakan 11 jam. Sedangkan jam buat kerja rumah yang dilakukan suami, sebanyak 51,67\% menyatakan hanya 2 jam, sebanyak 33,33\% 


\section{ARTIKEL}

menyatakan 3 jam, sebanyak 8,34\% menyatakan 3 jam, sebanyak 3,33\% menyatakan masing-masing 6 jam dan 8 jam.

Pada satu sisi wanita berperanan dalam lapangan pekerjaan, di sisi lain nilai budaya masyarakat Sunda masih membagi pekerjaan domestik adalah tanggung jawab isteri. Hal ini perlu adanya pemecahan masalah sehingga tidak menimbulkan konflik dalam keluarga, akan tetapi justru harus mendatangkan ketenangan, keharmonisan, keserasian, dan keselarasan dalam kehidupan keluarga atau dalam ungkapan Sunda repeh, rapih, tiis ceuli herang mata (artinya kehidupan keluarga yang harmonis, beres, tidak terjadi percekcokan, dan pertengkaran). Jika wanita menghadapi cabaran perubahan dalam peranannya, hal ini bisa dilakukan oleh pasangan suami isteri khasnya masyarakat Sunda dengan duduk bersama bermusyawarah membicarakan berbagai persoalan yang terjadi dalam keluarga, sehingga isteri dan suami bida saling mengerti, mamahami, menghargai, dan melakukan perbaikan-perbaikan dalam mengarungi kehidupan keluarga, karena tujuan dari pembentukan keluarga itu sakral.

\section{Isu Keluarga Berencana}

Isu Perancangan Keluarga mencakup pengambilan keputusan dalam kehidupan keluarga mencakup: penentuan bilangan anak (seberapa jauh pemakaian alat-alat kontrasepsi), pengelolaan keuangan keluarga, sosialisasi atau pembelajaran terhadap anak, dan penentuan pendidikan anak

\section{a. Jumlah Anak}

Berdasarkan jawapan responden, sebanyak $55 \%$ memiliki anak dua orang sahaja, sebanyak 23,66\% mempunyai anak tiga orang, sebanyak $11,67 \%$ mempunyai 
1 orang anak, sebanyak 8\% mempunyai anak 4 orang, dan sebanyak 1,67\% tidak mempunyai anak. Bilangan anak yang dipunyai oleh keluarga Sunda khasnya dalam kajian ini mengalami perubahan jika dibandingkan dengan generasi sebelumnya yaitu dengan bilangan anak yang dimiliki oleh ibu (orang tua) responden, yaitu paling banyak $(22,00 \%)$ mempunyai bilangan anak 6 orang, sebanyak 16,34\% mempunyai bilangan anak 5 orang, sebanyak 13,33\% mempunyai bilangan anak 7 orang , sebanyak 13,00\% mempunyai bilangan anak 8 orang, sebanyak $11,00 \%$ mempunyai bilangan anak 4 orang, sebanyak 9,00\% mempunyai anak 3 orang, sebanyak 5,00\% mempunyai bilangan anak 2 orang, sebanyak 4,00\% memiliki bilangan anak 12 orang, sebanyak 3,00\% memiliki bilangan anak 9 orang, sebanyak 3,00\% memiliki bilangan anak 10 orang, bahkan sebanyak 0,33\% memiliki bilangan anak 18 orang. Jika dibuat perbandingan maka jumlah bilangan anak masa sekarang lebih banyak hanya memiliki 2 orang anak sahaja; sedangkan masa sebelumnya lebih banyak memiliki anak 5 dan 7 orang anak.

Penurunan bilangan anak pada keluarga Sunda di kota Bandung, didorong oleh memudarnya nilai-nilai lokal budaya Sunda tentang nilai anak, seperti ungkapan banyak anak, banyak rejeki (artinya banyak bilangan anak, banyak rijkinya); banyak anak berarti jaminan hari tua bagi para orang tua, semasa kini sudah tidak relevan. Pada era modenisasi dan globalisasi sekarang ini, penentuan bilangan anak harus direncanakan secara matang karena anak merupakan titipan atau amanah dari Tuhan yang harus dipertanggungjawabkan.

Pengambilan keputusan dalam pembentukkan keluarga terutama dalam merencanakan bilangan anak yang diinginkan, sebanyak 91,67\% responden samasama menyatakan keputusan merencanakan bilangan anak ditentukan oleh suami dan 


\section{ARTIKEL}

E-ISSN: $2615-5028$

isteri. Hal ini terlihat dari ungkapan responden ketika menjawap mengenai keputusan untuk keluarga berencana, yang diilakukan bersama-sama antara suami dan isteri.

\section{b. Keluarga Berencana}

Semua responden menyatakan ikut serta dalam program keluarga berencana dengan pelbagai macam alat kontrasepsi, seperti suntik 46,67\%, menggunakan pil $8,33 \%$, dan IUD 45,00\%. Hal ini dilakukan untuk mengawal kehamilan sehingga akan terwujud norma keluarga kecil bagia sejahtera. Hampir semua responden atau sebanyak 91,67\% menyatakan bahwa keluarga berencana dilakukan atas kehendak suami dan isteri, serta sisanya $8,33 \%$ kemauan isteri lebih dominan dibandingkan dengan kemauan suami. Ini berarti pada tingkat personal, diisyaratkan adanya kesetaraan dalam pengambilan keputusan antara pasangan suami isteri dan keperdulian suami akan hak dan kesehatan seksual dan reproduksi. Hak reproduksi serta hak atas kesehatan reproduksi merupakan hak yang paling esensial dalam diri wanita.

\section{c. Dimensi Sosial}

Berdasarkan jawapan responden, sebanyak $55 \%$ memiliki anak dua orang sahaja, sebanyak $23,66 \%$ mempunyai anak tiga orang, sebanyak $11,67 \%$ mempunyai 1 orang anak, sebanyak 8\% mempunyai anak 4 orang, dan sebanyak 1,67\% tidak mempunyai anak. Bilangan anak yang dipunyai oleh keluarga Sunda khasnya dalam kajian ini mengalami perubahan jika dibandingkan dengan generasi sebelumnya yaitu dengan bilangan anak yang dimiliki oleh ibu (orang tua) responden, yaitu paling banyak (22,00\%) mempunyai bilangan anak 6 orang, sebanyak 16,34\% mempunyai 
bilangan anak 5 orang, sebanyak 13,33\% mempunyai bilangan anak 7 orang , sebanyak 13,00\% mempunyai bilangan anak 8 orang, sebanyak 11,00\% mempunyai bilangan anak 4 orang, sebanyak 9,00\% mempunyai anak 3 orang, sebanyak 5,00\% mempunyai bilangan anak 2 orang, sebanyak 4,00\% memiliki bilangan anak 12 orang, sebanyak 3,00\% memiliki bilangan anak 9 orang, sebanyak 3,00\% memiliki bilangan anak 10 orang, bahkan sebanyak 0,33\% memiliki bilangan anak 18 orang. Jika dibuat perbandingan maka jumlah bilangan anak masa sekarang lebih banyak hanya memiliki 2 orang anak sahaja; sedangkan masa sebelumnya lebih banyak memiliki anak 5 dan 7 orang anak.

Mengenai pengambilan keputusan dalam keluarga, khas dalam hal pengelolaan keuangan keluarga, sebanyak 54,00\% responden menyatakan isteri lebih dominan dari suami dalam mengelola keuangan keluarga, sedangkan 46,00\% menyatakan isteri dan suami seimbang dalam mengelola keuangan keluarga. Pengelolaan keuangan keluarga meliputi pengelolaan dalam pemenuhan kebutuhan pokok keluarga, meliputi sandang, pangan, perumahan, biaya pendidikan anak, serta perawatan kesehatan. Dalam masyarakat Sunda wanita dianggap lebih pandai dalam mengelola dan menyimpan keuangan, sesuai ungkapan Sunda awewe mah tempat padaringan, artinya wanita diibaratkan tempat menyimpan beras. Hal ini mengandung makna yang dalam, bahwa wanita dapat mengelola keuangan dengan sebaik-baiknya dibandingkan dengan lelaki.

Dalam proses pengajaran atau sosialisasi anak sebanyak 45,00\% responden menyatakan isteri lebih dominan dari suami, sedangkan sebanyak 55,00\% menyatakan isteri dan suami seimbang. Hal ini menunjukkan bahwa suami dan isteri mempunyai peranan yang sama dalam proses pengajaran terhadap anak-anaknya. 


\section{ARTIKEL}

Dalam masyarakat Sunda, peranan orang tua, terutama ayah dan ibu yang membentuk keluarga inti, tidak dapat diabaikan. Masyarakat Sunda yang menganut garis keturunan secara bilateral, dimana garis keturunan ibu dan garis keturunan ayah adalah sama dihadapan anak, turut membentuk proses sosialisasi anak, dimana orang tua mendapat tempat yang tinggi. Dalam ungkapan kearifan lokal orang Sunda, terungkap; "ari munjung kudu ka indung, muja mah kudu ka bapa (artinya yang harus disembah itu bukanlah gunung atau tempat-tempat angker, melainkan ibu dan ayah sendiri).

Dalam penentuan pendidikan anak, sebanyak 40,00\% responden menyatakan isteri lebih dominan dari suami, sedangkan sebanyak $60,00 \%$ menyatakan isteri dan suami seimbang. Hal ini menunjukkan bahwa suami dan isteri mempunyai peranan yang sama dalam proses penentuan pendidikan terhadap anak-anaknya.

\section{Kesimpulan}

Model perubahan peranan wanita Sunda merupakan model yang unik, dibendung oleh environment (lingkungan) yang berbeda dimana faktor agama sangat penting, karena agama memiliki peran yang strategis dalam mewujudkan kondisi moral, etika, norma, serta spiritual bangsa Indonesia khususnya etnis Sunda di Kota Bandung. Agama menjadi ageman atau petunjuk hidup yang membimbing dan mengatur prilaku masyarakat, sehingga agama harus diaplikasikan dalam kehidupan darigama (kehidupan sehari-hari).

Dalam pelaksanaan peranan wanita di Kota Bandung, faktor-faktor keserasian, keselarasan, dan keseimbangan hidup, kerukunan, kedamaian, keutuhan keluarga, dan musyawarah antara suami dan isteri sangatlah mengemuka. Keluarga 


\section{ARTIKEL}

E-ISSN: $2615-5028$

Indonesia mempunyai kode etika sendiri yang sulit difahami oleh dunia luar. Bila wanita menghadapi cabaran perubahan, maka dilakukanlah negosiasi dengan cara duduk bersama serta dirundingkan melalui musyawarah adalah merupakan sarana yang biasanya dilakukan dalam keluarga Indonesia, khasnya keluarga Sunda sehingga dengan musyawarah menimbulkan sistem saling pengertian, dan saling membantu, saling menghormati antara suami dan isteri; hal ini sesuai dengan ungkapan masyarakat Sunda “kudu pabeuyeuk-heuyeuk leungeun”, (saling bantu membantu), sabobot sapihanean, (kehidupan yang harmonis), ka cai jadi saleuwi ka darat jadi salebak (seiring sejalan dalam kebersamaan). Sistem saling pengertian, saling membantu, saling menghormati secara harmonis ini jarang terdapat dalam kehidupan keluarga di Negara-negara Barat yang pada umumnya mengagungkan rasionalitas. Hal ini, menunjukkan bahwa pola-pola hidup berkeluarga di Kota Bandung mempunyai nilainilai kodrati yang tinggi.

\section{DAFTAR PUSTAKA}

Adimihardja, Kusnaka. Dinamika Budaya Lokal. Indra Prahasta bersama Pusat Kajian LBPB, 2008.

Ekadjati, Edi S. Masyarakat Sunda dan Kebudayaanya. Bandung: Girimukti, 1984.

Ekajati, Edi Suhardi. Kebudayaan Sunda: Suatu Pendekatan Sejarah. Vol. 1. Pustaka Jaya, 1995.

Elliott, Anthony. Social theory and psychoanalysis in transition: Self and society from Freud to Kristeva. Routledge, 2019. 


\section{ARTIKEL}

E-ISSN: $2615-5028$

GBHN. Republik Indonesia 1988-1993. Jakarta: Sinar Wijaya. 1988.

Hassan, Nik Rushdi, Lars Mathiassen, and Paul Benjamin Lowry. "The process of information systems theorizing as a discursive practice." Journal of Information Technology (2019): 0268396219832004.

Hoang, Dong. "Labour Standards in the Global Supply Chain: Workers' Agency and Reciprocal Exchange Perspective." Societies 9, no. 2 (2019): 38.

Kumar, Ranjit. Research methodology: A step-by-step guide for beginners. Sage Publications Limited, 2019.

Mutawali. Peranan Wanita dalam Pembangunan Desa. Bandung: Karya Nusantara, 1987.

Rahman, M. Taufiq. Pengantar Filsafat Sosial. Bandung: LEKKAS. 2018.

Ritzer, George. Sociological Theory. New York: Alfred A. Knopf, 1988.

Rostiyati, Ani, and Aquarini Priyatna. "PEREMPUAN PUNK: BUDAYA PERLAWANAN TERHADAP GENDER NORMATIF (Kasus di Desa Cijambe Ujung Berung)." Patanjala: Jurnal Penelitian Sejarah dan Budaya 9, no. 2 (2017): 261-276.

Vredenbreght, J. Metode Dan Teknik Penyelidikan Masyarakat. Jakarta: Gramedia, 1997. 